\title{
Disinfection By-Products: Presence and Elimination in Drinking Water
}

\author{
Djamel Ghernaout ${ }^{1,2 *}$, Noureddine Elboughdiri ${ }^{1,3}$ \\ ${ }^{1}$ Chemical Engineering Department, College of Engineering, University of Ha'il, Ha'il, Saudi Arabia \\ ${ }^{2}$ Chemical Engineering Department, Faculty of Engineering, University of Blida, Blida, Algeria \\ ${ }^{3}$ Département de Génie Chimique de Procédés, Laboratoire Modélisation, Analyse, et Commande des systèmes, Ecole Nationale \\ d’Ingénieurs de Gabès (ENIG), Gabès, Tunisia \\ Email: ${ }^{\star d j a m e l \_a n d a l u s @ h o t m a i l . c o m ~}$
}

How to cite this paper: Ghernaout, D. and Elboughdiri, N. (2020) Disinfection ByProducts: Presence and Elimination in Drinking Water. Open Access Library Journal, 7: e6140.

https://doi.org/10.4236/oalib.1106140

Received: February 5, 2020

Accepted: February 18, 2020

Published: February 21, 2020

Copyright $\odot 2020$ by author(s) and Open Access Library Inc.

This work is licensed under the Creative Commons Attribution International License (CC BY 4.0).

http://creativecommons.org/licenses/by/4.0/

\begin{abstract}
The most frequently utilized technique for demobilizing pathogens remains disinfection. This is a fundamental stage in drinking water treatment as it removes the hazards related to water-borne diseases like typhoid and cholera. Therefore, disinfecting water employing chemical oxidants such as chlorine has been one of the main public health progresses through the previous century. During the time that this preserves the residual concentrations of disinfectant for the control of microbes, it may greatly elevate the generation of disinfection by-products (DBPs). Lately, Chaukura et al. [1] published an excellent review of the presence of organic matter (OM) in water sources and assessed its impact on the generation of DBPs. Especially, they discussed the production of DBPs, examined the contribution of OM on DBPs generation, and estimated and recommended techniques for eliminating DBPs. This work focuses on the main findings obtained by Chaukura et al. [1] and explores the authors' experience in dealing with disinfection processes and their DBPs generation issues as well as the techniques to remove them from water. Enhanced coagulation and membrane processes are efficacious in eliminating OM. An efficacious and economically usable procedure to dominate the production of DBPs in water treatment plants is to eliminate the precursors before they interact with chemical disinfectants, which should be avoided or at least reduced.
\end{abstract}

\section{Subject Areas}

Environmental Sciences

\section{Keywords}

Water Treatment, Disinfection, Disinfection By-Products, Water Treatment Plants (WTPs), Membrane Processes, Enhanced Coagulation 


\section{Introduction}

The most frequently utilized technique for demobilizing pathogens remains disinfection [1]. This is a fundamental stage in drinking water treatment as it removes the hazards related to water-borne diseases like typhoid and cholera [2]. Therefore, disinfecting water employing chemical oxidants has been one of the main public health progresses through the previous century [3] [4] [5]. The variety of disinfectants utilized comprises oxidants like chlorine, chloramine, chlorine dioxide $\left(\mathrm{ClO}_{2}\right)$, and ozone [6]. Among these, chlorine is the most largely employed worldwide thanks to its lower price and its capability to generate huge volumes of $\mathrm{ClO}_{2}$. On the other hand, chlorination is efficient versus most microbes, may interact with manganese and iron [7] to avert unpleasant organoleptic features, and preserves residual chlorine concentrations in the distribution system [8] [9]. Usually, disinfection is employed at water treatment plants (WTPs) [10] [11] [12] [13]; however, for prolonged distribution systems, it can be requested to inject disinfectants in the distribution system, via a booster chlorination system [14]. During the time that this preserves the residual concentrations of disinfectant for the control of microbes, it may greatly elevate the generation of disinfection by-products (DBPs) [15] [16]. Nevertheless, it is substantial to emphasize that when assessing DBPs and their monitoring, the beneficial public health contribution of disinfection should not be missed [17].

Features like residence period, $\mathrm{pH}$, and temperature affect the performance of the disinfection technology [1] [18]. A huge investigation on DBPs has been performed to comprehend the generation phenomena throughout the remediation techniques and the distribution system, as well as the likely human health effects [19]. Disinfectants interact with natural organic matter (NOM) in treated water and the distribution system to form DBPs, which comprise haloacetic acids (HAAs), iodo- and fluoro-compounds, and trihalomethanes (THMs) (Figure 1) [20] [21] [22]. Between these, THMs and HAAs are the most examined as their concentrations are greatly more elevated than other DBPs [23] [24] [25].

Several DBPs have been specified as carcinogenic, mutagenic, and reproductive toxicants, and so cause a serious hazard to human health [19]. The human subjection to DBPs is via diverse routes like absorbing water holding elevated DBP concentrations, inhaling DBPs in the air when water is vigorously mixed [26], and via dermal contact [1] [23]. Because of the inherent harmful impacts on human health, the United States Environmental Protection Agency (USEPA) has developed threshold limits for many DBPs in potable water [27].

In potable water, the generation and level of DBPs are affected via the kind of killing microorganisms' agent, physicochemical characteristics of the raw water, treatment plant running cases, the temperature of the water, and the contact period of the water in the distribution system [1] [24] [28] [29]. Many models have been utilized to anticipate the DBP generation capacity and the behavior in WTPs and distribution systems [30]. Such models are helpful in operational decision-making to reduce exposure, and to establish threshold limits and guidelines [31] [32]. 


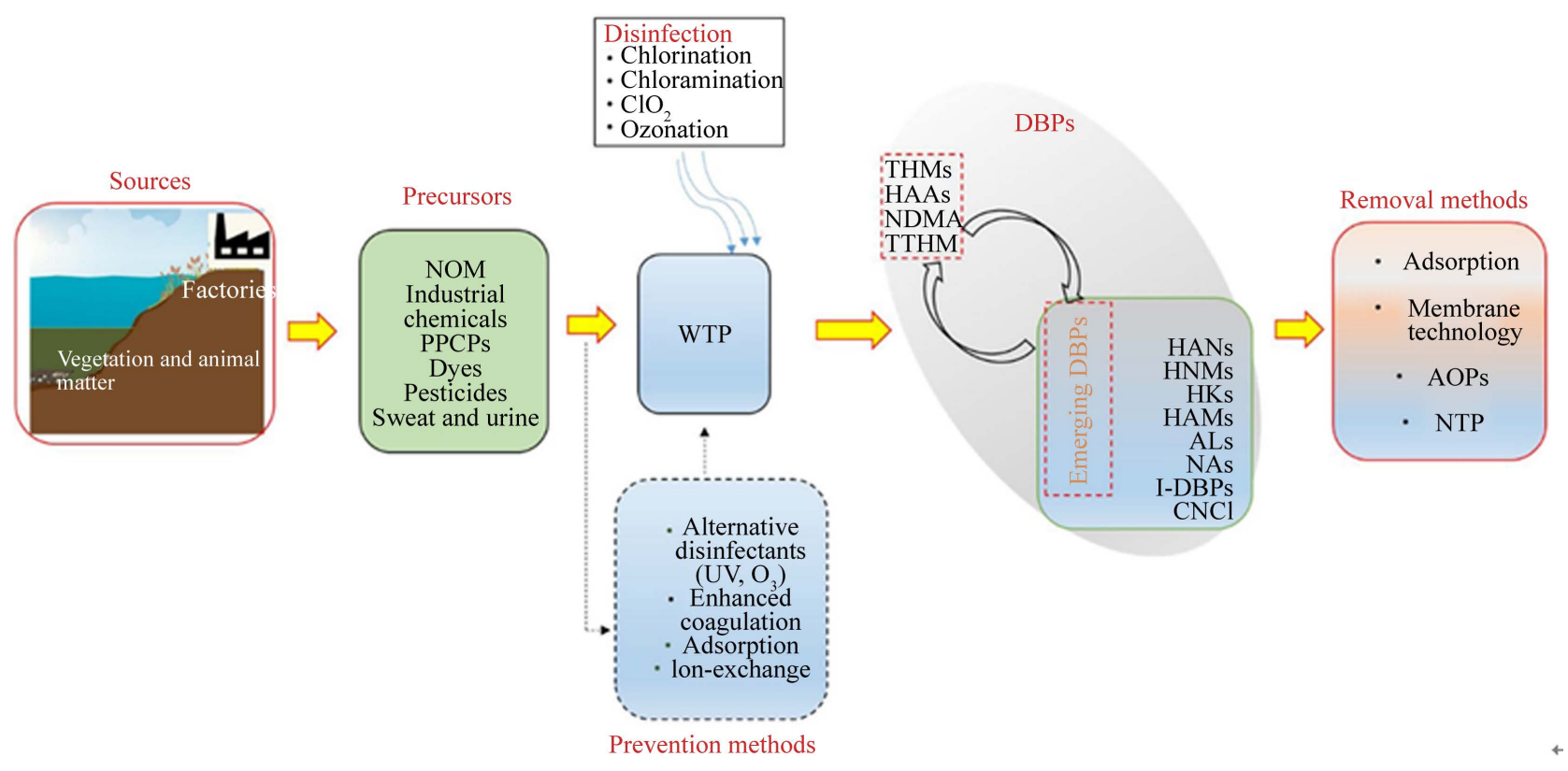

Figure 1. Schematic showing the range, sources, precursors, and preventative and removal methods for DBPs [1].

DBPs generation is foremost related to chlorination [33]. To avoid this, several substitutional disinfectants like chloramines, ozone, and $\mathrm{ClO}_{2}$ have been tried [34]. The main benefit of chloramine is that it diminishes the production of regulated DBPs and other chemicals like geosmin and 2-methyl isoborneol, which induce unwanted organoleptic features in potable water [35] [36] [37] [38]. Further, chloramine possesses the capacity to dominate the development of biofilms as it permeates biofilms more efficaciously than chlorine. On the other hand, chloramination may lead to the production of $N$-nitrosamines (NAs), which are themselves carcinogenic [19]. Notwithstanding being an efficacious disinfection method, ozonation is probable to produce DBPs like bromates if there are considerable levels of bromide existing in the source water [39]. Even if substitutional disinfectants diminish the production of numerous DBPs comparative to chlorination, they have given rise to novel worries by forming a fresh category of DBPs famous as emerging DBPs [40]. Moreover, emerging DBPs have as well been specified from chlorination application [41]. This implicates chemicals like as aldehydes, cyanides, halonitromethanes (HNMs), haloketones (HKs), haloacetamides, iodinated-DBPs (I-DBPs), and NAs [42]. Consequently, present investigations concentrate more on comprehending the generation pathways, concentrations, and the involved dangerous health influences of emerging DBPs [1]. Many investigations on the spatial and temporal existences of emerging DBPs in distribution systems have been performed [43] [44]. Also, technological progress in sampling, extraction, and analytical capacities has allowed the detection and quantification of emerging DBPs, even at trace concentrations.

As seen above, the DBPs are unwanted in treated water as they are greatly carcinogenic to humans [45]. Thus, it is vital to efficiently eliminate NOM and other DBP precursors to prevent such water quality and running issues throughout 
water treatment [1] [46] [47]. Protective actions may employ substitutional disinfectants that do not conduct to DBP generation [48] [49]. Elimination processes that have been examined comprise enhanced coagulation [50], ion-exchange, advanced oxidation processes (AOPs) [51], and membrane processes [52] [53] (Figure 1). An efficacious and economically feasible procedure to dominate the generation of DBPs in WTPs is to eliminate the precursors before they interact with disinfectants [54]. Even if organic matter (OM) may be removed, the bromide ion stays in traditional WTPs. Therefore, many WTPs have concentrated on eliminating precursors like NOM for monitoring DBPs [55].

Chaukura et al. [1] published a comprehensive review of the presence of NOM in water sources and assess its impact on the generation of DBPs. Especially, they discussed the production of DBPs, examined the contribution of NOM on DBP generation, and estimated and recommended techniques for eliminating DBPs. This work focuses on the main findings obtained by Chaukura et al. [1] and explores the authors' experience in dealing with disinfection processes and their DBPs generation issues as well as the techniques to remove them from water.

\section{Generation of Disinfection By-Products (DBPs)}

As aforesaid, the production of DBPs and their levels in potable water are touched by parameters like properties of the source water, disinfectant sorts, running factors, water temperature and $\mathrm{pH}$, and the contact period of the water in the WTP and distribution system [56] [57]. For instance, the water sources of coastal regions are frequently submitted to saltwater intrusion, conducting to augmented I-DBPs and brominated disinfection by-products (Br-DBPs) generation [58] [59]; however, chloramines and NAs usually are found in swimming pools, wastewater, groundwater, and potable water [1] [60].

More than 700 DBPs produced from diverse disinfectant procedures have been discovered in final potable water [61]. Investigating NOM is usually realized to juxtapose NOM properties and its impact on the treatability and DBP generation throughout the disinfection stage with the finale target to regulate the NOM reduction technique [38] [62]. In the domain of the drinking water supply industry, for the most part, the halogenated DBPs (THMs and HAAs) are regulated because of their repeated presence by mass in definitive potable water [63] [64]. While the regulatory limits for HAAs and THMs fixed by the USEPA are $60 \mu \mathrm{g} / \mathrm{L}$, and $80 \mu \mathrm{g} / \mathrm{L}$, respectively, in Europe the guideline value for THMs is $100 \mu \mathrm{g} / \mathrm{L}[1]$ [65].

In addition to elevated levels of THMs and HAAs being observed in ultimate potable water, other DBPs like HNMs, haloacetonitriles (HANs), haloaldehyde, and iodo-THMs (I-THMs) have also been noted in considerable quantities [66]. In the face of being actually unregulated, emerging DBPs greatly participate more in the poisoning of chlorinated water than regulated DBPs [1].

More details about the contribution of NOM on DBPs production may be 
found in [1].

\section{Emerging Disinfection By-Products (DBPs)}

Not long ago, a fresh category of unregulated DBPs has drawn research interest. This involves aldehydes, cyanides, HANs, HNMs, HKs, haloacetamides, NAs, and I-DBPs (Table 1) [67]. Restricted understanding of such emerging DBPs implies that they are not controlled in the potable water treatment and distribution systems [1] [68] [69].

Away from NOM, anthropogenic pollutants like bromide and iodide compounds interact with chlorine, chloramine, chlorine dioxide and ozone to generate DBPs with featured chemical properties [70] [71] [72]. Anthropogenic organic contaminants originate from manufacturing industries and domestic wastewaters. Several of such contaminants may interact with disinfectants employed in potable water treatment to form particular DBPs [73] [74]. Organic contaminants that generate DBPs via interacting with disinfectants involve diverse categories of pharmaceuticals, personal care products, estrogens, pesticides, industrial additives, antibacterial agents, textile dyes, and ethoxylate surfactants [61]. The bromide and iodide ions serve as the inorganic precursors of DBPs [1].

Table 1. Emerging DBPs [1] [70] [71] [72].

\begin{tabular}{|c|c|c|}
\hline $\begin{array}{l}\text { Emerging } \\
\text { DBPs }\end{array}$ & Production circumstances & $\begin{array}{l}\text { Frequent } \\
\text { concentration } \\
\text { intervals }\end{array}$ \\
\hline HANs & $\begin{array}{l}\text { Produced during the disinfection of water employing } \\
\text { chlorination, chloramination, and chlorine dioxide. }\end{array}$ & $0.6-24 \mu \mathrm{g} / \mathrm{L}$ \\
\hline HNMs & $\begin{array}{l}\text { Formed if pre-ozonation is utilized before chlorine or } \\
\text { chloramine disinfection. }\end{array}$ & $0.16-1.50 \mu \mathrm{g} / \mathrm{L}$ \\
\hline $\mathrm{HKs}$ & $\begin{array}{l}\text { The HKs levels change along the distribution system because } \\
\text { of base-catalyzed hydrolysis reactions. }\end{array}$ & $1.23-8.6 \mu \mathrm{g} / \mathrm{L}$ \\
\hline $\begin{array}{l}\text { Halomethanes } \\
\text { (HMs) }\end{array}$ & $\begin{array}{l}\text { Produced in the water distribution system after chloramination } \\
\text { and ozonation without biofiltration, which hydrolyses HANs } \\
\text { to HMs. }\end{array}$ & $1.50-7.0 \mu \mathrm{g} / \mathrm{L}$ \\
\hline Aldehydes & $\begin{array}{l}\text { Ozonation likely improves the production of low molecular } \\
\text { weight oxygen-carrying by-products, conducting to the } \\
\text { generation of halogenated aldehydes. Throughout chlorination, } \\
\text { trihalogenated species are more probably to be produced. The } \\
\text { generation of non-halogenated Aldehydes, which comprises } \\
\text { acetaldehyde and formaldehyde, is provoked by integrating } \\
\text { chlorine and other oxidants as disinfectants. }\end{array}$ & - \\
\hline NAs & $\begin{array}{l}\text { The generation of NAs is provoked by the reaction among } \\
\text { monochloramine and organic amine precursors throughout } \\
\text { chloramination. Further, NAs are as well formed from the } \\
\text { chlorination of nitrite in the existence of nitrosamine } \\
\text { precursors. }\end{array}$ & $10-90 \mathrm{ng} / \mathrm{L}$ \\
\hline I-DBPs & $\begin{array}{l}\text { Appear if water is chlorinated, chloroaminated, or ozonated in } \\
\text { the existence of iodide. }\end{array}$ & $0.54-0.9 \mu \mathrm{g} / \mathrm{L}$ \\
\hline Cyanides & & $* 4 \mu \mathrm{g} / \mathrm{L}$ \\
\hline
\end{tabular}

*The mean concentration of $\mathrm{CNCl}$ in water distribution systems. 


\section{Techniques for Removing Disinfection By-Products (DBPs)}

The reason of eliminating NOM is to restrict the generation of DBPs in the definitive potable water provided to consumers [1] [75]. The treatability of OM, in general, must be pre-determined to attain the best-fit control procedures since numerous techniques are a function of the kind of source water inside a specific location, and, by extension, of the properties of the source water [73]. Usually utilized DBP control strategies involve the elimination of DBP precursors and the employment of substitutional disinfectants. Because of DBPs having various precursors, the reaction mechanism that implicates disinfection is particular to each group of the DBP produced throughout the disinfection stage. Thus, it is proposed that procedures to decrease DBPs have to concentrate on evaluating the precursor in the individual water source and its next DBP production [68]. Consequently, there is presently not a unique process that will reduce all DBPs throughout water treatment [76]. Use has been made of alum and ferric sulfate coagulation [77], intermediate ozonation $\left(\mathrm{iO}_{3}\right)$, powdered activated carbon (PAC), magnetic ion exchange, and nanofiltration (NF) [73]. Each of these techniques possesses diverse dissolved organic carbon (DOC) reduction efficiencies.

The efficient elimination of DBPs may be obtained via several methods like adsorption, anion exchange, biological treatment [78], enhanced coagulation, membrane processes [79] [80], and AOPs [81]. Adsorption and enhanced coagulation processes are two large scale techniques that may be efficaciously employed for controlling DBPs [1] [35].

When produced, DBPs may be eliminated throughout treatment in the WTPs or post-treatment in the distribution system. Several DBPs like HAAs and THMs may be efficiently eliminated utilizing activated carbons in point-of-use carbon treatment devices [42]. As the adsorption capacity of granular activated carbon (GAC) for DBPs is low, bioactivity on the GAC surface efficiently reduces biodegradable DBPs like aldehydes, HAAs, and ketoacids [42]. Biologically active carbon efficiently eliminates HAAs generated throughout pre-chlorination or intermediate chlorination steps [82] [83]. More elevated water temperatures, longer empty bed residence periods, or mixing native GAC with a fraction of adapted GAC, lead to an ameliorated reduction. Nevertheless, the requirement of recurrent GAC change makes the technique costly [1].

Volatile DBPs may as well be decreased via air stripping [84], which is a cost-efficient technology for THMs elimination, especially in small water treatments setups or in THMs hot spots in big distribution systems [42]. Thanks to the elevated distribution constant, air stripping is more performant in summer when THMs production is highest, and less efficacious when brominated THMs are predominant. Nevertheless, air stripping is less performant in reducing DBPs contrasted to adsorption on bioactive carbon [1]. Compared with chloramination and enhanced coagulation, air stripping does not produce toxic by-products [42]. Both chloramination and enhanced coagulation are more efficacious in 
summer when HAA and THM generation is highest.

\subsection{Enhanced Coagulation}

The coagulation process reduces hydrophobic NOM portions from water more efficiently because of their lower affinity, higher molecular weights and charge density [85]. This has demanded more survey into regulating the coagulation method to attain enhanced coagulation mainly for total organic carbon (TOC) elimination [1]. There are two likely routes for particulate and organics elimination by metal salt coagulants: charge neutralization and sweep flocculation [50] [86]. Charge neutralization takes place via the generation of multi-charge complexes with improved adsorption. Such routes need a particular $\mathrm{pH}$ domain for optimum efficiency [87] [88]. Charge neutralization stimulates metal species to link with the anionic sites on the organic material [50]. Sweep flocculation happens when huge injections of mineral salt coagulants are utilized and very enormous hydroxide precipitates are produced [86]. The particles begin to be enmeshed in the precipitate and may be "swept" out of the water throughout sedimentation [50]. Nevertheless, the route is a function of coagulant addition and water quality [86] [89].

Enhanced coagulation diminishes the $\mathrm{pH}$ of the water during the introduction of coagulant, and $\mathrm{pH}$ adjusting chemicals if needed [90]. The method employs metal salt coagulants at injections usually bigger than for turbidity reduction [1] [87] [91]. Such coagulation technology operates on hydrophilic and hydrophobic NOM proportions more via charge neutralization than sweep coagulation, and is appropriate without pre-oxidation or pre-chlorination [35] [92]. Nevertheless, the performance of enhanced coagulation is a function of regulating the coagulant injection, and $\mathrm{pH}$ [93].

The most frequently employed metal salt coagulants remain aluminum salts (like aluminum chloride, aluminum sulfate, and sodium aluminate and ferric salts (like ferric chloride, ferric sulfate, and ferrous sulfate) [35] [94]. The optimum hydrolyzing $\mathrm{pH}$ for aluminum salts is 5.5 - 7.7 [51]. Nevertheless, if the $\mathrm{pH}$ is diminished under such optimum, positively charged dissolved alum compounds are produced [1]. This is convenient for eliminating NOM since it is mainly constituted of negatively charged compounds [95] [96]. For ferric salts, the optimum $\mathrm{pH}$ is $4.5-7.0$ with injections ranging among $5-150 \mathrm{mg} / \mathrm{L}$ and 20 - $250 \mathrm{mg} / \mathrm{L}$ for ferric chloride and sulfate, respectively [77].

\subsection{Membrane Technologies}

The membrane is a discerning barrier that utilizes size exclusion and diffusion pathways to separate molecules [97]. Following their characteristics, membranes are employed in different orders and usages. Illustrations are reverse osmosis (RO), NF, microfiltration (MF), and ultrafiltration (UF) membranes. Since each membrane technique possesses a single DOC elimination capacity, membrane selection greatly relies on the pollutants existing in water. Not only does size ex- 
clusion and electrostatic repulsion affect DOC rejection; however, as well the aromatic property of DOC touches rejection of OM via the membrane [98]. The main issue in employing membranes for NOM removal remains membrane fouling, which diminishes flux and performance [99] [100]. As a result, water is mostly pre-treated prior membrane techniques because direct filtration is not wanted when thinking about the usage of membrane remediation. Thanks to the benefit of modification using nanomaterials, utilizations of membrane techniques have hugely augmented in water and wastewater treatment [101]. Numerous reports noted that membrane fouling may be lessen through embodying nanoparticles into membranes [102]. If humic acids are added to membranes containing nanoparticles, the humic acid molecules [103] [104] [105] [106] can be absorbed and fill voids between nanoparticles on the membrane surface [1].

\subsubsection{Reverse Osmosis (R0)}

Reverse osmosis (RO) is a high pressure technique. It is usually utilized in water and wastewater treatment. Under usual circumstances RO does not possess the capability to eliminate contaminants like THMs and other volatile organic compounds (VOCs) [69]. At lower levels, however, RO setups are performant in dealing with VOCs, THMs, and numerous other organic and inorganic contaminants. Further, RO setups may be employed in dealing with seriously contaminated or untreatable water sources. Considerable pre-treatment of water is needed before $\mathrm{RO}$ to eliminate particulate and colloidal material to guarantee that the membrane is kept [1].

\subsubsection{Nanofiltration (NF)}

As a pressure driven membrane method, NF appears as an in-between among $\mathrm{RO}$ and UF techniques, and has features of both. NF is a low pressure technique that can eliminate contaminants like NOM, small organic molecules, and DBPs precursors [24]. Therefore, it may be employed in dealing with potable water for small communities. Plus, it is able to eliminate microorganisms and diminish the generation of DBPs precursors. Further, it is low-cost and simple to run. Consequently, it may be utilized for water and wastewater treatment and in the pharmaceutical and food industries. Nevertheless, NF necessitates pre-treatment, has high energy need, has brine disposal dares [107], and is prone to fouling [108] [109]. Identical to RO, this setup is able of simultaneously eliminating both organic and inorganic DBP precursors [1]. However, surface modification of the membrane like grafting hydrophilic monomers is not completely efficacious in decreasing fouling.

\subsubsection{Ultrafiltration (UF)}

UF is an economically interesting water treatment technique utilized in industrial water treatment. The UF membranes possess wide pore size distributions and various surface charge densities, and are fabricated from different materials. They decrease turbidity, suspended solids, and THMs precursors; however, they are not efficacious in dealing with humic substances with high HAAs and THMs 
formation potentials [1]. Even if charged, UF membranes possess higher NOM reduction capabilities, and many NOM portions are too small and are not efficiently retained by the UF membranes. Usually, charged membranes are more vulnerable to $\mathrm{pH}$ change than neutral membranes. Nevertheless, UF membranes have the potential to eliminate DPB precursors at laboratory scale; however, assimilable organic carbon (AOC) is not efficiently eliminated since they are normally small molecular weight compounds [110]. Thanks to the linear configuration and a large molecular radius, the elimination of NOM is more readily realized via size exclusion and charge repulsion under alkaline circumstances. Then, UF is frequently utilized as a pretreatment step in NF and RO methods, which are able of eliminating microorganisms. Even with the cost-effectiveness, UF is restricted by fouling which provokes pressure drop and makes recurrent cleaning needed. Membrane fouling is induced by microbial growth, and colloidal and scale precipitation on the membrane surface [24]. Fouling may be diminished via some pretreatment techniques like coagulation, adsorption, or ozonation [111].

\subsubsection{Microfiltration (MF)}

MF method is frequently employed for eliminating particulate matter from water. This technique may be utilized for highly turbid water as a pretreatment step for NF or RO, or as a stand-alone method [54]. Except if fixe to particulate matter, DOC cannot be efficaciously eliminated via MF. MF membranes possess pore sizes bigger than NOM molecules, thus they are inefficacious for eliminating NOM [49]. Plus, NOM tends to attach to pores and settle onto the surface of the membrane, in the end provoking pore obstruction [49] [54]. Consequently, membrane fouling of this type may be monitored via pre-treatment through coagulation/flocculation to eliminate NOM [1].

\subsubsection{Ceramic Membranes}

The efficiency of a membrane is dictated by its capability to keep a constant flux and resist fouling. NOM remains the major fouling in potable water, and its fouling tendency is decided by membrane characteristics like the charge, hydrophobicity, surface roughness, and NOM features like the charge, hydrophobicity, and size [1]. Additional fundamental factors are the solution flux, $\mathrm{pH}$, ionic strength, hardness, and surface shear. Usually, most membranes utilized in potable water treatment have been produced of organic polymers. Nevertheless, there has been an augmentation in the attention on membranes formed of ceramic materials. Ceramic membranes are usually less vulnerable to fouling than polymeric membranes and the fouling routes are unlike. More important, ceramic membranes may be cleaned employing aggressive chemicals that may deteriorate polymeric equivalents. Therefore, ceramic membranes have been established to possess a better efficiency than similar polymeric membranes. Thanks to such advantages, ceramic membranes are encouraging for the eliminating NOM from potable water. Up to lately, the higher price of ceramic membranes 
has restricted their implementation. Nevertheless, as a consequence of manufacturing enhancements, the global life cost of ceramic membranes and their ameliorated water quality have made them so desirable [1].

\subsection{UV-Founded Technology}

Employing halogen-free disinfection techniques like ozone and UV diminishes halogenated DBPs generation [112] [113]. Further, UV is largely utilized for killing microorganisms in water that carries protozoans like Cryptosporidium and Giardia, because chlorination is less efficient in monitoring such pathogens [114] [115]. As no lasting disinfectant may be kept in UV treatment, chlorine or chloramine have been merged with UV irradiation as attendant disinfection to give an enduring in the distribution network [44]. Probably, this procedure ultimately eliminates a few DBPs like inorganic chloramines, and elevates the production of THMs and HANs [38]. The levels and features of DBP precursors are the basic parameters touching the global DBPs production in natural waters [1]. UV irradiation may change the molecular weight and the hydrophobicity of DBP precursors, and thus modify the reactivity of NOM with chlorine. In addition, UV irradiation potentially augments the amount of AOC [44].

\subsection{Advanced Oxidation Processes (AOPs)}

AOPs utilize hydroxyl radicals as the principal oxidant to effect water remediation. The hydroxyl radical is produced when an oxidizing agent interacts with organic contaminants in water [81]. The diverse AOPs for eliminating NOM comprise ozone $\left(\mathrm{O}_{3}\right)$, ozone/hydrogen peroxide $\left(\mathrm{O}_{3} / \mathrm{H}_{2} \mathrm{O}_{2}\right)$, ozone/ultraviolet radiation $\left(\mathrm{O}_{3} / \mathrm{UV}\right)$, hydrogen peroxide/ultra-violet radiation $\left(\mathrm{H}_{2} \mathrm{O}_{2} / \mathrm{UV}\right)$, titanium dioxide/ultraviolet radiation $\left(\mathrm{TiO}_{2} / \mathrm{UV}\right), \mathrm{O}_{3} /$ catalyst, ozone/hydrogen peroxide/ultra-violet radiation, Fenton and photo-Fenton processes, ultrasound, and non-thermal plasma (NTP) [116]. The most significant side of AOPs is their potential to totally mineralize organic pollutants below ambient temperature and pressure; however, this needs huge energy and chemical consumption [117]. At the injections and levels frequently implemented in water treatment, there is a danger that AOPs can convert both micro-contaminants and NOM into precursors of DBPs that may be more or less reactive with disinfectants than the parent compound [1] [12] [13].

AOPs are categorized into photochemical and non-photochemical AOPs. While the photochemical method produces hydroxyl radicals employing UV radiation with $\mathrm{H}_{2} \mathrm{O}_{2}, \mathrm{O}_{3}$ and/or $\mathrm{Fe}^{2+}$, the non-photochemical method forms hydroxyl radicals in the obscurity of light, either via ozonation or Fenton response [118]. The photochemical method $\mathrm{UV} / \mathrm{H}_{2} \mathrm{O}_{2}$ is the AOP that is usually employed for treating potable water [118]. Employing $\mathrm{H}_{2} \mathrm{O}_{2}$ as disinfectant of potable water is restricted by its instability throughout storage; however, its performance in monitoring microbial growth is debated [81]. In general, implementing AOPs is a function of the kind of pollutants existing in water [1]. 


\section{Next Research Trends}

The property of OM in a source water requires to be constantly estimated, and OM elimination performances obtained by the WTP should be controlled [1] [119] [120] [121].

Lately, numerous engineered nanomaterials have shown to be efficient disinfectants. Employing such materials does not conduct to the formation of halogenated DBPs. This involves materials like zero valent metals, of which a broader domain could be examined for the decomposition of DBP precursors and already generated DBPs. Utilization may be realized of nanoparticle-based membranes to alleviate fouling. Nevertheless, while such materials are efficacious at a laboratory scale, their commercial implementation is not so far economically practicable [1] [122].

\section{Conclusions}

From this work, the following conclusions can be drawn:

1) Some portions of NOM contribute in the production of DBPs.

2) Membrane processes, enhanced coagulation, AOPs, and NTP method are efficacious in eliminating NOM, even if AOP techniques are usually not economically realizable and yet require more expansion and up-scaling.

3) Price is a basic factor in selecting a water treatment technology. An efficacious and economically usable procedure to dominate the production of DBPs in WTPs is to eliminate the precursors before they interact with disinfectants. An equilibrium stays to be discovered among an elevated enough chlorine remaining to monitor the bio-stability of the water, and low sufficiently to reduce the DBP generation [1] [123].

\section{Conflicts of Interest}

The authors declare no conflicts of interest regarding the publication of this paper.

\section{References}

[1] Chaukura, N., Marais, S.S., Moyo, W., Mbali, N., Thakalekoala, L.C., Ingwani, T., Mamba, B.B., Jarvis, P. and Nkambule, T.T.I. (2020) Contemporary Issues on the Occurrence and Removal of Disinfection Byproducts in Drinking Water-A Review. Journal of Environmental Chemical Engineering, 8, Article ID: 103659. https://doi.org/10.1016/j.jece.2020.103659

[2] Postigo, C., Emiliano, P., Barcelo, D. and Valero, F. (2018) Chemical Characterization and Relative Toxicity Assessment of Disinfection Byproduct Mixtures in a Large Drinking Water Supply Network. Journal of Hazardous Materials, 359, 166-173. https://doi.org/10.1016/j.jhazmat.2018.07.022

[3] Ghernaout, D. and Ghernaout, B. (2010) From Chemical Disinfection to Electrodisinfection: The Obligatory Itinerary? Desalination and Water Treatment, 16, 156-175. https://doi.org/10.5004/dwt.2010.1085

[4] Ghernaout, D., Touahmia, M. and Aichouni, M. (2019) Disinfecting Water: Elec- 
trocoagulation as an Efficient Process. Applied Engineering, 3, 1-12.

[5] Ghernaout, D., Aichouni, M. and Touahmia, M. (2019) Mechanistic Insight into Disinfection by Electrocoagulation-A Review. Desalination and Water Treatment, 141, 68-81. https://doi.org/10.5004/dwt.2019.23457

[6] Ghernaout, D. (2019) Greening Electrocoagulation Process for Disinfecting Water. Applied Engineering, 3, 27-31.

[7] Ghernaout, D. (2017) The Holy Koran Revelation: Iron Is a "Sent Down" Metal. American Journal of Environmental Protection, 6, 101-104. https://doi.org/10.11648/j.ajep.20170604.14

[8] Ghernaout, D. (2017) Environmental Principles in the Holy Koran and the Sayings of the Prophet Muhammad. American Journal of Environmental Protection, 6, 75-79. https://doi.org/10.11648/j.ajep.20170603.13

[9] Ndlangamandla, N.G., Kuvarega, A.T., Msagati, T.A.M., Mamba, B.B. and Nkambule, T.T.I. (2018) A Novel Photodegradation Approach for the Efficient Removal of Natural Organic Matter (NOM) from Water. Physics and Chemistry of the Earth, Parts $A / B / C, 106,97-106$. https://doi.org/10.1016/j.pce.2018.05.011

[10] Alshammari, Y., Ghernaout, D., Aichouni, M. and Touahmia, M. (2018) Improving Operational Procedures in Riyadh's (Saudi Arabia) Water Treatment Plants Using Quality Tools. Applied Engineering, 2, 60-71.

[11] Ghernaout, D., Aichouni, M. and Alghamdi, A. (2018) Applying Big Data (BD) in Water Treatment Industry: A New Era of Advance. International Journal of Advanced and Applied Sciences, 5, 89-97. https://doi.org/10.21833/ijaas.2018.03.013

[12] Ghernaout, D., Aichouni, M., Alghamdi, A. and Ait Messaoudene, N. (2018) Big Data: Myths, Realities and Perspectives-A Remote Look. American Journal of Information Science and Technology, 2, 1-8. https://doi.org/10.11648/j.ajist.20180201.11

[13] Ghernaout, D., Aichouni, M. and Alghamdi, A. (2018) Overlapping ISO/IEC 17025:2017 into Big Data: A Review and Perspectives. International Journal of Science and Qualitative Analysis, 4, 83-92.

[14] Ghernaout, D. and Elboughdiri, N. (2019) Water Disinfection: Ferrate(VI) as the Greenest Chemical-A Review. Applied Engineering, 3, 171-180.

[15] Belhout, D., Ghernaout, D., Djezzar-Douakh, S. and Kellil, A. (2010) Electrocoagulation of a Raw Water of Ghrib Dam (Algeria) in Batch Using Iron Electrodes. Desalination and Water Treatment, 16, 1-9. https://doi.org/10.5004/dwt.2010.1081

[16] Ghernaout, D., Benblidia, C. and Khemici, F. (2015) Microalgae Removal from Ghrib Dam (Ain Defla, Algeria) Water by Electroflotation Using Stainless Steel Electrodes. Desalination and Water Treatment, 54, 3328-3337. https://doi.org/10.1080/19443994.2014.907749

[17] Ghernaout, D. and Elboughdiri, N. (2019) Mechanistic Insight into Disinfection Using Ferrate(VI). Open Access Library Journal, 6, e5946. https://doi.org/10.4236/oalib.1105946

[18] Ghernaout, D., Elboughdiri, N. and Ghareba, S. (2019) Drinking Water Reuse: One-Step Closer to Overpassing the "Yuck Factor". Open Access Library Journal, 6, e5895. https://doi.org/10.4236/oalib.1105895

[19] Kristiana, I., Liew, D., Henderson, R.K., Joll, C.A. and Linge, K.L. (2017) Formation and Control of Nitrogenous DBPs from Western Australian Source Waters: Investigating the Impacts of High Nitrogen and Bromide Concentrations. Journal of Environmental Sciences, 58, 102-115. https://doi.org/10.1016/j.jes.2017.06.028 
[20] Hua, G., Reckhow, D.A. and Abusallout, I. (2015) Correlation between SUVA and DBP Formation during Chlorination and Chloramination of NOM Fractions from Different Sources. Chemosphere, 130, 82-89. https://doi.org/10.1016/j.chemosphere.2015.03.039

[21] Golea, D.M., Upton, A., Jarvis, P., Moore, G., Sutherland, S., Parsons, S.A. and Judd, S.J. (2017) THM and HAA Formation from NOM in Raw and Treated Surface Waters. Water Research, 112, 226-235. https://doi.org/10.1016/j.watres.2017.01.051

[22] Zainudin, F.M., Hasan, H.A. and Abdullah, S.R.S. (2018) An Overview of the Technology Used to Remove Trihalomethane (THM), Trihalomethane Precursors, and Trihalomethane Formation Potential (THMFP) from Water and Wastewater. Journal of Industrial and Engineering Chemistry, 57, 1-14. https://doi.org/10.1016/j.jiec.2017.08.022

[23] Islam, N., Sadiq, R., Rodriguez, M.J. and Legay, C. (2016) Assessing Regulatory Violations of Disinfection By-Products in Water Distribution Networks Using a Non-Compliance Potential Index. Environmental Monitoring and Assessment, 188, 304. https://doi.org/10.1007/s10661-016-5306-3

[24] Marais, S.S., Ncube, E.J., Msagati, T.A.M., Mamba, B.B. and Nkambule, T.T.I. (2018) Comparison of Natural Organic Matter Removal by Ultrafiltration, Granular Activated Carbon Filtration and Full Scale Conventional Water Treatment. Journal of Environmental Chemical Engineering, 6, 6282-6289.

https://doi.org/10.1016/j.jece.2018.10.002

[25] Marais, S.S., Ncube, E.J., Msagati, T.A.M., Mamba, B.B. and Nkambule, T.T.I. (2019) Assessment of Trihalomethane (THM) Precursors Using Specific Ultraviolet Absorbance (SUVA) and Molecular Size Distribution (MSD). Journal of Water Process Engineering, 27, 143-151. https://doi.org/10.1016/j.jwpe.2018.11.019

[26] Ghernaout, D. and Boucherit, A. (2015) Review of Coagulation's Rapid Mixing for NOM Removal. Journal of Research \& Developments in Chemistry, 2015, Article ID: 926518. https://doi.org/10.5171/2015.926518

[27] USEPA (2009) National Primary Drinking Water Regulations. USEPA, USA, 7.

[28] Ghernaout, D. (2017) Microorganisms’ Electrochemical Disinfection Phenomena. EC Microbiology, 9, 160-169.

[29] Ghernaout, D., Alghamdi, A. and Ghernaout, B. (2019) Microorganisms' Killing: Chemical Disinfection vs. Electrodisinfection. Applied Engineering, 3, 13-19.

[30] Ndiweni, S.N., Chys M., Chaukura, N., Van Hulle, S.W.H. and Nkambule, T.T.I. (2019) Assessing the Impact of Environmental Activities on Natural Organic Matter in South Africa and Belgium. Environmental Technology, 40, 1756-1768. https://doi.org/10.1080/09593330.2019.1575920

[31] Ghernaout, D., Badis, A., Ghernaout, B. and Kellil, A. (2008) Application of Electrocoagulation in Escherichia coli Culture and two Surface Waters. Desalination, 219, 118-125. https://doi.org/10.1016/j.desal.2007.05.010

[32] Ghernaout, D., Ghernaout, B. and Boucherit, A. (2008) Effect of pH on Electrocoagulation of Bentonite Suspensions in Batch Using Iron Electrodes. Journal of Dispersion Science and Technology, 29, 1272-1275. https://doi.org/10.1080/01932690701857483

[33] Ghernaout, D., Elboughdiri, N. and Al Arni, S. (2019) Water Reuse (WR): Dares, Restrictions, and Trends. Applied Engineering, 3, 159-170.

[34] Ghernaout, D. (2019) Disinfection via Electrocoagulation Process: Implied Mechanisms and Future Tendencies. EC Microbiology, 15, 79-90. 
[35] Ghernaout, D. (2014) The Hydrophilic/Hydrophobic Ratio vs. Dissolved Organics Removal by Coagulation-A Review. Journal of King Saud University-Science, 26, 169-180. https://doi.org/10.1016/j.jksus.2013.09.005

[36] Ghernaout, D., Badis, A., Braikia, G., Matâam, N., Fekhar, M., Ghernaout, B. and Boucherit, A. (2017) Enhanced Coagulation for Algae Removal in a Typical Algeria Water Treatment Plant. Environmental Engineering and Management Journal, 16, 2303-2315. https://doi.org/10.30638/eemj.2017.238

[37] Kellali, Y. and Ghernaout, D. (2019) Physicochemical and Algal Study of Three Dams (Algeria) and Removal of Microalgae by Enhanced Coagulation. Applied Engineering, 3, 56-64.

[38] Ghernaout, D., Ghernaout, B. and Kellil, A. (2009) Natural Organic Matter Removal and Enhanced Coagulation as a Link between Coagulation and Electrocoagulation. Desalination and Water Treatment, 2, 203-222.

https://doi.org/10.5004/dwt.2009.116

[39] Ding, S., Chu, W., Bond, T., Cao, Z., Xu, B. and Gao, N. (2018) Contribution of Amide-Based Coagulant Polyacrylamide as Precursors of Haloacetamides and Other Disinfection By-Products. Chemical Engineering Journal, 350, 356-363. https://doi.org/10.1016/j.cej.2018.06.002

[40] Ghernaout, D. and Elboughdiri, N. (2019) Water Reuse: Emerging Contaminants Elimination-Progress and Trends. Open Access Library Journal, 6, e5981. https://doi.org/10.4236/oalib.1105981

[41] Ghernaout, D., Elboughdiri, N. and Alghamdi, A. (2019) Direct Potable Reuse: The Singapore NEWater Project as a Role Model. Open Access Library Journal, 6, e5980. https://doi.org/10.4236/oalib.1105980

[42] Wang, X., Mao, Y., Tang, S., Yang, H. and Xie, Y.F. (2015) Disinfection Byproducts in Drinking Water and Regulatory Compliance: A Critical Review. Frontiers of Environmental Science \& Engineering, 9, 3-15. https://doi.org/10.1007/s11783-014-0734-1

[43] Andersson, A., Ashiq, M.J., Shoeb, M., Karlsson, S., Bastviken, D. and Kylin, H. (2019) Evaluating Gas Chromatography with a Halogen-Specific Detector for the Determination of Disinfection By-Products in Drinking Water. Environmental Science and Pollution Research, 26, 7305-7314.

https://doi.org/10.1007/s11356-018-1419-2

[44] Chen, S., Deng, J., Li, L. and Gao, N. (2018) Evaluation of Disinfection By-Product Formation during Chlor(am)ination from Algal Organic Matter after UV Irradiation. Environmental Science and Pollution Research, 25, 5994-6002. https://doi.org/10.1007/s11356-017-0918-x

[45] Zha, X.S., Ma, L.M., Wu, J. and Liu, Y. (2016) The Removal of Organic Precursors of DBPs during Three Advanced Water Treatment Processes Including Ultrafiltration, Biofiltration, and Ozonation. Environmental Science and Pollution Research, 23, 16641-16652. https://doi.org/10.1007/s11356-016-6643-z

[46] Ghernaout, D., Ghernaout, B. and Naceur, M.W. (2011) Embodying the Chemical Water Treatment in the Green Chemistry-A Review. Desalination, 271, 1-10. https://doi.org/10.1016/j.desal.2011.01.032

[47] Ghernaout, D. (2018) Magnetic Field Generation in the Water Treatment Perspectives: An Overview. International Journal of Advanced and Applied Sciences, 5, 193-203. https://doi.org/10.21833/ijaas.2018.01.025

[48] Ramavandi, B., Farjadfard, S., Ardjmand, M. and Dobaradaran, S. (2015) Effect of Water Quality and Operational Parameters on Trihalomethanes Formation Poten- 
tial in Dez River Water, Iran. Water Resources and Industry, 11, 1-12. https://doi.org/10.1016/j.wri.2015.03.002

[49] Osawa, H., Lohwacharin, J. and Takizawa, S. (2017) Controlling Disinfection By-Products and Organic Fouling by Integrated Ferrihydrite-Microfiltration Process for Surface Water Treatment. Separation and Purification Technology, 176, 184-192. https://doi.org/10.1016/j.seppur.2016.12.003

[50] Eslami, H., Ehrampoush, M.H., Esmaeili, A., Salmani, M.H., Ebrahimi, A.A., Ghaneian, M.T., Falahzadeh, H. and Fard, R.F. (2019) Enhanced Coagulation Process by Fe-Mn Bimetal Nano-Oxides in Combination with Inorganic Polymer Coagulants for Improving $\mathrm{As}(\mathrm{V})$ Removal from Contaminated Water. Journal of Cleaner Production, 208, 384-392. https://doi.org/10.1016/j.jclepro.2018.10.142

[51] Sillanpaa, M., Ncibi, M.C., Matilainen, A. and Vepsalainen, M. (2018) Removal of Natural Organic Matter in Drinking Water Treatment by Coagulation: A Comprehensive Review. Chemosphere, 190, 54-71.

https://doi.org/10.1016/j.chemosphere.2017.09.113

[52] Huang, W., Lv, W., Zhou, W., Hu, M. and Dong, B. (2019) Investigation of the Fouling Behaviors Correlating to Water Characteristics during the Ultrafiltration with Ozone Treatment. Science of the Total Environment, 676, 53-61. https://doi.org/10.1016/j.scitotenv.2019.04.271

[53] Ghernaout, D. and El-Wakil, A. (2017) Requiring Reverse Osmosis Membranes Modifications-An Overview. American Journal of Chemical Engineering, 5, 81-88. https://doi.org/10.11648/j.ajche.20170504.15

[54] Chellam, S. and Sari, M.A. (2016) Aluminum Electrocoagulation as Pretreatment during Microfiltration of Surface Water Containing NOM: A Review of Fouling, NOM, DBP, and Virus Control. Journal of Hazardous Materials, 304, 490-501. https://doi.org/10.1016/j.jhazmat.2015.10.054

[55] Kim, J. and Kang, B. (2008) DBPs Removal in GAC Filter-Adsorber. Water Research, 42, 145-152. https://doi.org/10.1016/j.watres.2007.07.040

[56] Krasner, S.W. (2009) The Formation and Control of Emerging Disinfection By-Products of Health Concern. Philosophical Transactions of the Royal Society A: Mathematical, Physical and Engineering Sciences, 367, 4077-4095. https://doi.org/10.1098/rsta.2009.0108

[57] Ghernaout, D. and Elboughdiri, N. (2019) Upgrading Wastewater Treatment Plant to Obtain Drinking Water. Open Access Library Journal, 6, e5959. https://doi.org/10.4236/oalib.1105959

[58] Pan, Y., Zhang, X. and Zhai, J. (2015) Whole Pictures of Halogenated Disinfection Byproducts in Tap Water from China's Cities. Frontiers of Environmental Science \& Engineering, 9, 121-130. https://doi.org/10.1007/s11783-014-0727-0

[59] Deeudomwongsa, P., Phattarapattamawong, S. and Lin, K.Y.A. (2017) Control of Disinfection Byproducts (DBPs) by Ozonation and Peroxone Process: Role of Chloride on Removal of DBP Precursors. Chemosphere, 184, 1215-1222.

https://doi.org/10.1016/j.chemosphere.2017.06.105

[60] Catto, C., Sabrina, S., Ginette, C.T., Manuel, R. and Robert, T. (2012) Occurrence and Spatial and Temporal Variations of Disinfection By-Products in the Water and Air of Two Indoor Swimming Pools. International Journal of Environmental Research and Public Health, 9, 2562-2586. https://doi.org/10.3390/ijerph9082562

[61] Richardson, S.D., Plewa, M.J., Wagner, E.D., Schoeny, R. and Demarini, D.M. (2007) Occurrence, Genotoxicity, and Carcinogenicity of Regulated and Emerging Disinfection By-Products in Drinking Water: A Review and Roadmap for Research. 
Mutation Research, 663, 178-242. https://doi.org/10.1016/j.mrrev.2007.09.001

[62] Gough, R., Holliman, P.J., Willis, N., Jones, T.G. and Freeman, C. (2012) Influence of Habitat on the Quantity and Composition of Leachable Carbon in the $\mathrm{O}_{2}$ Horizon: Potential Implications for Potable Water Treatment. Lake and Reservoir Management, 28, 282-292. https://doi.org/10.1080/07438141.2012.741187

[63] USEPA (2006) National Primary Drinking Water Regulations: Stage 2 Disinfectants and Disinfection Byproducts Rule. Federal Register, 387-493.

[64] Health Canada (2019) Guidelines for Canadian Drinking Water Quality-Summary Table. Water and Air Quality Bureau, Healthy Environments and Consumer Safety Branch, Health Canada, Ottawa, Ontario.

[65] WHO (2005) Trihalomethanes in Drinking-Water-Background Document for Development of WHO Guidelines for Drinking-Water Quality.

[66] Bond, T., Goslan, E.H., Parsons, S.A. and Jefferson, B. (2012) A Critical Review of Trihalomethane and Haloacetic Acid Formation from Natural Organic Matter Surrogates. Environmental Technology Reviews, 1, 93-113.

https://doi.org/10.1080/09593330.2012.705895

[67] Carter, R.A.A., Liew, D.S., West, N., Heitz, A. and Joll, C.A. (2019) Simultaneous Analysis of Haloacetonitriles, Haloacetamides and Halonitromethanes in Chlorinated Waters by Gas Chromatography Mass Spectrometry. Chemosphere, 220, 314-323. https://doi.org/10.1016/j.chemosphere.2018.12.069

[68] Ghernaout, D. and Elboughdiri, N. (2020) Antibiotics Resistance in Water Mediums: Background, Facts, and Trends. Applied Engineering, 4, 1-6. https://doi.org/10.4236/oalib.1106003

[69] Ghernaout, D. and Elboughdiri, N. (2020) Removing Antibiotic-Resistant Bacteria (ARB) Carrying Genes (ARGs): Challenges and Future Trends. Open Access Library Journal, 7, e6003. https://doi.org/10.4236/oalib.1106003

[70] Ghernaout, D., Naceur, M.W. and Aouabed, A. (2011) On the Dependence of Chlorine By-Products Generated Species Formation of the Electrode Material and Applied Charge during Electrochemical Water Treatment. Desalination, 270, 9-22. https://doi.org/10.1016/j.desal.2011.01.010

[71] Ghernaout, D., Alghamdi, A., Aichouni, M. and Touahmia, M. (2018) The Lethal Water Tri-Therapy: Chlorine, Alum, and Polyelectrolyte. World Journal of Applied Chemistry, 3, 65-71. https://doi.org/10.11648/j.wjac.20180302.14

[72] Ghernaout, D. (2017) Water Treatment Chlorination: An Updated Mechanistic Insight Review. Chemistry Research Journal, 2, 125-138.

[73] Ghernaout, D. and Naceur, M.W. (2011) Ferrate(VI): In Situ Generation and Water Treatment-A Review. Desalination and Water Treatment, 30, 319-332. https://doi.org/10.5004/dwt.2011.2217

[74] Ghernaout, D. (2017) Water Reuse (WR): The Ultimate and Vital Solution for Water Supply Issues. International Journal of Sustainable Development Research, 3, 36-46. https://doi.org/10.11648/j.ijsdr.20170304.12

[75] Ghernaout, D. (2018) Increasing Trends towards Drinking Water Reclamation from Treated Wastewater. World Journal of Applied Chemistry, 3, 1-9. https://doi.org/10.11648/j.wjac.20180301.11

[76] Ghernaout, D., Alghamdi, A. and Ghernaout, B. (2019) Electrocoagulation Process: A Mechanistic Review at the Dawn of Its Modeling. Journal of Environmental Science and Allied Research, 2, 51-67. https://doi.org/10.29199/2637-7063/ESAR-201019 
[77] Ghernaout, D., Laribi, C., Alghamdi, A., Ghernaout, B., Ait Messaoudene, N. and Aichouni, M. (2018) Decolorization of BF Cibacete Blue (CB) and Red Solophenyle 3BL (RS) Using Aluminum Sulfate and Ferric Chloride. World Journal of Applied Chemistry, 3, 32-40. https://doi.org/10.11648/j.wjac.20180302.11

[78] Ghernaout, D. (2019) Reviviscence of Biological Wastewater Treatment-A Review. Applied Engineering, 3, 46-55.

[79] Ghernaout, D. (2017) Reverse Osmosis Process Membranes Modeling-A Historical Overview. Journal of Civil, Construction and Environmental Engineering, 2, 112-122.

[80] Ghernaout, D., El-Wakil, A., Alghamdi, A., Elboughdiri, N. and Mahjoubi, A. (2018) Membrane Post-Synthesis Modifications and How It Came about. International Journal of Advanced and Applied Sciences, 5, 60-64. https://doi.org/10.21833/ijaas.2018.02.010

[81] Ghernaout, D. (2013) Advanced Oxidation Phenomena in Electrocoagulation Process: A Myth or a Reality? Desalination and Water Treatment, 51, 7536-7554. https://doi.org/10.1080/19443994.2013.792520

[82] Ghernaout, D., Alshammari, Y. and Alghamdi, A. (2018) Improving Energetically Operational Procedures in Wastewater Treatment Plants. International Journal of Advanced and Applied Sciences, 5, 64-72. https://doi.org/10.21833/ijaas.2018.09.010

[83] Al Arni, S., Amous, J. and Ghernaout, D. (2019) On the Perspective of Applying of a New Method for Wastewater Treatment Technology: Modification of the Third Traditional Stage with Two Units, One by Cultivating Microalgae and Another by Solar Vaporization. International Journal of Environmental Sciences \& Natural Resources, 16, Article ID: 555934. https://doi.org/10.19080/IJESNR.2019.16.555934

[84] Ghernaout, D. (2019) Aeration Process for Removing Radon from Drinking Water-A Review. Applied Engineering, 3, 32-45.

[85] Ghernaout, D., Al-Ghonamy, A.I., Naceur, M.W., Boucherit, A., Messaoudene, N.A., Aichouni, M., Mahjoubi, A.A. and Elboughdiri, N.A. (2015) Controlling Coagulation Process: From Zeta Potential to Streaming Potential. American Journal of Environmental Protection, 4, 16-27. https://doi.org/10.11648/j.ajeps.s.2015040501.12

[86] Ghernaout, D. and Ghernaout, B. (2012) Sweep Flocculation as a Second Form of Charge Neutralisation-A Review. Desalination and Water Treatment, 44, 15-28. https://doi.org/10.1080/19443994.2012.691699

[87] Ghernaout, D. (2017) Entropy in the Brownian Motion (BM) and Coagulation Background. Colloid and Surface Science, 2, 143-161.

[88] Ghernaout, D., Simoussa, A., Alghamdi, A., Ghernaout, B., Elboughdiri, N., Mahjoubi, A., Aichouni, M. and El-Wakil, A.E.A. (2018) Combining Lime Softening with Alum Coagulation for Hard Ghrib Dam Water Conventional Treatment. International Journal of Advanced and Applied Sciences, 5, 61-70. https://doi.org/10.21833/ijaas.2018.05.008

[89] Ghernaout, B., Ghernaout, D. and Saiba, A. (2010) Algae and Cyanotoxins Removal by Coagulation/Flocculation: A Review. Desalination and Water Treatment, 20, 133-143. https://doi.org/10.5004/dwt.2010.1202

[90] Ghernaout, D. and Ghernaout, B. (2012) On the Concept of the Future Drinking Water Treatment Plant: Algae Harvesting from the Algal Biomass for Biodiesel Production-A Review. Desalination and Water Treatment, 49, 1-18. https://doi.org/10.1080/19443994.2012.708191 
[91] Djezzar, S., Ghernaout, D., Cherifi, H., Alghamdi, A., Ghernaout, B. and Aichouni, M. (2018) Conventional, Enhanced, and Alkaline Coagulation for Hard Ghrib Dam (Algeria) Water. World Journal of Applied Chemistry, 3, 41-55. https://doi.org/10.11648/j.wjac.20180302.12

[92] Ghernaout, D., Al-Ghonamy, A.I., Boucherit, A., Ghernaout, B., Naceur, M.W., Ait Messaoudene, N., Aichouni, M., Mahjoubi, A.A. and Elboughdiri, N.A. (2015) Brownian Motion and Coagulation Process. American Journal of Environmental Protection, 4, 1-15. https://doi.org/10.11648/j.ajeps.s.2015040501.11

[93] Ghernaout, D. (2013) The Best Available Technology of Water/Wastewater Treatment and Seawater Desalination: Simulation of the Open Sky Seawater Distillation. Green and Sustainable Chemistry, 3, 68-88. https://doi.org/10.4236/gsc.2013.32012

[94] Ghernaout, D., Naceur, M.W. and Ghernaout, B. (2011) A Review of Electrocoagulation as a Promising Coagulation Process for Improved Organic and Inorganic Matters Removal by Electrophoresis and Electroflotation. Desalination and Water Treatment, 28, 287-320. https://doi.org/10.5004/dwt.2011.1493

[95] Ghernaout, D., Moulay, S., Ait Messaoudene, N., Aichouni, M., Naceur, M.W. and Boucherit, A. (2014) Coagulation and Chlorination of NOM and Algae in Water Treatment: A Review. International Journal of Environmental Monitoring and Analysis, 2, 23-34. https://doi.org/10.11648/j.ijema.s.2014020601.14

[96] Boucherit, A., Moulay, S., Ghernaout, D., Al-Ghonamy, A.I., Ghernaout, B., Naceur, M.W., Ait Messaoudene, N., Aichouni, M., Mahjoubi, A.A. and Elboughdiri, N.A. (2015) New Trends in Disinfection By-Products Formation upon Water Treatment. Journal of Research \& Developments in Chemistry, 2015, Article ID: 628833. https://doi.org/10.5171/2015.628833

[97] Ghernaout, D. and Elboughdiri, N. (2020) Magnetic Field Application: An Underappreciated Outstanding Technology. Open Access Library Journal, 7, e6000.

[98] Irki, S., Ghernaout, D., Naceur, M.W., Alghamdi, A. and Aichouni, M. (2018) Decolorizing Methyl Orange by Fe-Electrocoagulation Process-A Mechanistic Insight. International Journal of Environmental Chemistry, 2, 18-28. https://doi.org/10.11648/j.ijec.20180201.14

[99] Ghernaout, D., Alshammari, Y., Alghamdi, A., Aichouni, M., Touahmia, M. and Ait Messaoudene, N. (2018) Water Reuse: Extenuating Membrane Fouling in Membrane Processes. International Journal of Environmental Chemistry, 2, 1-12. https://doi.org/10.11648/j.ajche.20180602.12

[100] Irki, S., Ghernaout, D. and Naceur, M.W. (2017) Decolourization of Methyl Orange (MO) by Electrocoagulation (EC) Using Iron Electrodes under a Magnetic Field (MF). Desalination and Water Treatment, 79, 368-377. https://doi.org/10.5004/dwt.2017.20797

[101] Ghernaout, D. and Elboughdiri, N. (2020) Electrochemical Technology for Wastewater Treatment: Dares and Trends. Open Access Library Journal, 7, e6020.

[102] Ait Messaoudene, N., Naceur, M.W., Ghernaout, D., Alghamdi, A. and Aichouni, M. (2018) On the Validation Perspectives of the Proposed Novel Dimensionless Fouling Index. International Journal of Advanced and Applied Sciences, 5, 116-122. https://doi.org/10.21833/ijaas.2018.07.014

[103] Ghernaout, D., Ghernaout, B., Saiba, A., Boucherit, A. and Kellil, A. (2009) Removal of Humic Acids by Continuous Electromagnetic Treatment Followed by Electrocoagulation in Batch Using Aluminium Electrodes. Desalination, 239, 295-308. https://doi.org/10.1016/j.desal.2008.04.001

[104] Ghernaout, D., Ghernaout, B., Boucherit, A., Naceur, M.W., Khelifa, A. and Kellil, 
A. (2009) Study on Mechanism of Electrocoagulation with Iron Electrodes in Idealised Conditions and Electrocoagulation of Humic Acids Solution in Batch Using Aluminium Electrodes. Desalination and Water Treatment, 8, 91-99. https://doi.org/10.5004/dwt.2009.668

[105] Ghernaout, D., Mariche, A., Ghernaout, B. and Kellil, A. (2010) Electromagnetic Treatment-Bi-Electrocoagulation of Humic Acid in Continuous Mode Using Response Surface Method for its Optimization and Application on Two Surface Waters. Desalination and Water Treatment, 22, 311-329.

https://doi.org/10.5004/dwt.2010.1120

[106] Ghernaout, D., Irki, S. and Boucherit, A. (2014) Removal of $\mathrm{Cu}^{2+}$ and $\mathrm{Cd}^{2+}$, and Humic Acid and Phenol by Electrocoagulation Using Iron Electrodes. Desalination and Water Treatment, 52, 3256-3270. https://doi.org/10.1080/19443994.2013.852484

[107] Ghernaout, D. (2019) Brine Recycling: Towards Membrane Processes as the Best Available Technology. Applied Engineering, 3, 71-84.

[108] Ghernaout, D. (2019) Greening Cold Fusion as an Energy Source for Water Treatment Distillation-A Perspective. American Journal of Quantum Chemistry and Molecular Spectroscopy, 3, 1-5.

[109] Ghernaout, D., Alghamdi, A., Touahmia, M., Aichouni, M. and Ait Messaoudene, N. (2018) Nanotechnology Phenomena in the Light of the Solar Energy. Journal of Energy, Environmental \& Chemical Engineering, 3, 1-8. https://doi.org/10.11648/j.jeece.20180301.11

[110] Irki, S., Ghernaout, D., Naceur, M.W., Alghamdi, A. and Aichouni, M. (2018) Decolorization of Methyl Orange (MO) by Electrocoagulation (EC) Using Iron Electrodes under a Magnetic Field (MF). II. Effect of Connection Mode. World Journal of Applied Chemistry, 3, 56-64. https://doi.org/10.11648/j.wjac.20180302.13

[111] Saiba, A., Kourdali, S., Ghernaout, B. and Ghernaout, D. (2010) In Desalination, from 1987 to 2009, the Birth of a New Seawater Pretreatment Process: Electrocoagulation-An Overview. Desalination and Water Treatment, 16, 201-217. https://doi.org/10.5004/dwt.2010.1094

[112] Ghernaout, D. and Elboughdiri, N. (2019) Iron Electrocoagulation Process for Disinfecting Water-A Review. Applied Engineering, 3, 154-158.

[113] Ghernaout, D. and Elboughdiri, N. (2019) Electrocoagulation Process Intensification for Disinfecting Water-A Review. Applied Engineering, 3, 140-147.

[114] Ghernaout, D. (2019) Electrocoagulation Process for Microalgal Biotechnology-A Review. Applied Engineering, 3, 85-94.

[115] Ghernaout, D. (2018) Electrocoagulation Process: Achievements and Green Perspectives. Colloid and Surface Science, 3, 1-5. https://doi.org/10.11648/j.css.20180301.11

[116] Ghernaout, D., Elboughdiri, N. and Ghareba, S. (2020) Fenton Technology for Wastewater Treatment: Dares and Trends. Open Access Library Journal, 7, e6045. https://doi.org/10.4236/oalib.1106045

[117] Ghernaout, D. (2019) Virus Removal by Electrocoagulation and Electrooxidation: New Findings and Future Trends. Journal of Environmental Science and Allied Research, 2019, 85-90. https://doi.org/10.29199/2637-7063/ESAR-202024

[118] Ghernaout, D. (2019) Electrocoagulation and Electrooxidation for Disinfecting Water: New Breakthroughs and Implied Mechanisms. Applied Engineering, 3, 125-133.

[119] Ghernaout, D., Al-Ghonamy, A.I., Irki, S., Grini, A., Naceur, M.W., Ait Messaou- 
dene, N. and Aichouni, M. (2014) Decolourization of Bromophenol Blue by Electrocoagulation Process. Trends in Chemical Engineering, 15, 29-39.

[120] Ghernaout, D., Al-Ghonamy, A.I., Naceur, M.W., Ait Messaoudene, N. and Aichouni, M. (2014) Influence of Operating Parameters on Electrocoagulation of C.I. Disperse Yellow 3. Journal of Electrochemical Science and Engineering, 4, 271-283. https://doi.org/10.5599/jese.2014.0065

[121] Ghernaout, D., Al-Ghonamy, A.I., Ait Messaoudene, N., Aichouni, M., Naceur, M.W., Benchelighem, F.Z. and Boucherit, A. (2015) Electrocoagulation of Direct Brown 2 (DB) and BF Cibacete Blue (CB) Using Aluminum Electrodes. Separation Science and Technology, 50, 1413-1420.

https://doi.org/10.1080/01496395.2014.982763

[122] Ghernaout, D. (2018) Disinfection and DBPs Removal in Drinking Water Treatment: A Perspective for a Green Technology. International Journal of Advanced and Applied Sciences, 5, 108-117. https://doi.org/10.21833/ijaas.2018.02.018

[123] Ghernaout, D. and Elboughdiri, N. (2020) Is Not It Time to Stop Using Chlorine for Treating Water? Open Access Library Journal, 7, e6007. 